\title{
The aching of Dion Harper
}

\author{
A case of phantom body syndrome.
}

\section{Arthur Chrenkoff}

After the man with steel-blue eyes had killed me, he knelt down next to my body, pulled out a thin-bladed knife from a sheath strapped to his shin, and with one quick movement cut off my right ear. That wasn't a part of his contract; I guess he must have had a fetish for trophies.

Only moments earlier I had been pleading with him for my life, cornered like a rat, my back pressed against a locked exit door at the lowest level of the Metro Tower underground hoverpark. "I'm not Dion," I cried through chattering teeth, the realization of the imminent end squeezing the air out of my windpipe. "For God's sake, I'm not Dion. I don't..."

"Ain't that what all of them always say," the man with steel-blue eyes cut me off, a tinge of veteran's weariness colouring his voice. Behind us lay the trail of death - his dead associates, killed by my dead bodyguards - until there was only me, him and his gun remaining, all claustrophobically entombed underneath two hundred storeys of iron, polymer and glass.

"Either way, Dion, we'll find out soon enough," my killer said and then he extended his arm, aiming at my torso.

I have now watched my last moments through my killer's eyes. Minutes before the man with steel-blue eyes was dispatched with a single bullet to the back of the head, one of my best lieutenants and his support team downloaded a cache of my killer's memories. It took an outfit I subcontract in West Virginia almost 24 hours of non-stop work to separate a few useful grains from the chaff of the man's - by the way, his name was Heikke - life memories.

And so, a few hours later, I sat on a synth-skin sofa with a glass of scotch in my hand, watching the misty holo replay of the most interesting tidbits once stored in Heikke's mind; his contacts with midlevel operatives of the Syndicate, his pursuit and killing of me, and finally his own capture. For some reason, the guys in West Virginia thought that the bondage session Heikke had engaged in with a prostitute in Vegas the night before he killed me was somehow relevant. I fast-forwarded through it. Sometimes, I think, they do these things as a bit of a joke.

The rain is falling hard now, streaking the window and obscuring the view of the meadow as it gently slopes for a few hundred yards towards a little brook. One of Bruckner's symphonies is playing in the background, masking the gentle buzz of information streaming into five terminals around the room, connecting me to my far-flung empire.

I'm aching now. inside me compounds, growing like tree rings around my self, layer upon layer of longing. But it's still bearable. And, in the end, better them than me, isn't that right? So I'll deal with the ache.

There are another seven Dions waiting on stand-by. Now that the man with steelblue eyes has eliminated my previous public self, one of the reserve ones is being readied to enter circulation.

It's not cheap, these lives of mine. As the saying goes, only multibillionaires can afford to be multi. It costs ten million Standard Units to successfully
clone an individual, another (1) $\begin{aligned} & \text { clone an individual, another } \\ & \text { ten or more to bring the clone }\end{aligned}$ up, double that when you go for accelerated growth. And then there are the optional extras like the fake memory implants, which nowadays aren't all that optional anymore. After all, you can't make it too easy for those
who are hunting 1 you. The Dion one before last was so 1 good and so believable that for about 16 months the Syndicate really believed that this time they had finally managed to kill me. This hiatus in our dirty little tit-for-tat has bought me some very valuable time to further rearrange my many affairs.

But the war will go on, until the bitter end - theirs or mine. With the new Dion entering the arena as soon as the Syndicate satisfies itself beyond doubt that once again they did not get the real McCoy, I'll still have a half-a-dozen of me kept in reserve, ready to be called in at a short notice. And I can and will have still more. The sky's the limit. Or, more precisely, the limit is my resources, and they are considerable.

But there is only one me - the real me. Many vessels, though filled with the breath of life, but only one soul to go between them all. And I'm its proud sole owner. I'll be damned if I will let the Syndicate, or anyone else, steal that most precious of all my possessions.

I am Dion Harper. The one - but not only.

Arthur Chrenkoff is a Polish-Australian retired blogger. His first novel, The Night Trains is being published by Cold Spring Press. To the best of his knowledge, he hasn't been cloned yet. 